\title{
AVALIAÇÃO DA ATIVIDADE ANTIOXIDANTE PELA CAPTURA DE RADICAIS LIVRES 1,1-DIFENIL-2- PICRILHIDRAZILA PELO EXTRATO ETANÓLICO E FRAÇÕES DE FOLHAS DE Smilax sp.
}

Myriam Almeida Barbosa*, Juliana Costa Fonseca, Izabela Caputo Assis Silva, Ana Hortência Fonsêca Castro, Luciana Alves Rodrigues dos

Santos Lima

Universidade Federal de São João Del Rei - UFSJ - Campus Centro-Oeste Dona Lindu - Divinópolis/MG. *E-mail: myriambarbosa@gmail.com

\section{Resumo}

Antioxidantes são compostos que conseguem retardar ou impedir a oxidação de alguns substratos. $\mathrm{O}$ conhecimento da atividade antioxidante dos vegetais é de grande importância, visto que eles têm eficácia na prevenção de doenças relacionadas ao estresse oxidativo. Dessa forma, o objetivo deste trabalho foi avaliar a atividade antioxidante do extrato etanólico e frações obtidas de folhas de Smilax sp. As folhas de Smilax foram coletadas, secadas e trituradas. O extrato etanólico foi obtido por percolação com etanol e depois submetido à partição com hexano, diclorometano e acetato de etila, obtendo-se as frações hexânica, diclorometânica, acetoetílica e hidroetanólica. O 1,1-difenil-2-picrilhidrazila (DPPH) é um radical livre usado para avaliar a atividade antioxidante. A redução do DPPH por um antioxidante ou por espécies radicalares resultam na perda de absorbância em $517 \mathrm{~nm}$. Assim, o grau de descoloração da solução de DPPH indica a eficiência de remoção de radicais pela substância adicionada. A análise foi feita a partir de concentrações de 500, 250,100, 10 e $1 \mu \mathrm{g} / \mathrm{mL}$ do extrato etanólico e das frações, sendo lida a absorbância após 30 minutos em espectrofotômetro a $517 \mathrm{~nm}$. Os resultados obtidos no experimento mostraram que o extrato etanólico e as frações foram capazes de capturar o radical DPPH em todas as concentrações testadas, sendo a inibição dose-dependente. Todas as amostras apresentaram inibição do DPPH maior que $90 \%$ nas concentrações de 500 e $250 \mu \mathrm{g} / \mathrm{mL}$. A fração hexânica apresentou maior porcentagem de inibição 
com 98,44 \% na concentração de $500 \mu \mathrm{L}$, seguida pela diclorometânica, acetoetílica, hidroetanólica e extrato etanólico.

Palavras-chave: Smilax, atividade antioxidante, folhas.

Apoio financeiro: CNPq, FAPEMIG, CAPES, UFSJ 